Article

\title{
Effects of Different Fertilizers on Rhizosphere Bacterial Communities of Winter Wheat in the North China Plain
}

\author{
Rubiao Liang ${ }^{1,2}$, Ruixing Hou ${ }^{1}$, Jing Li ${ }^{1}$, Yun Lyu ${ }^{1,2}$, Sheng Hang ${ }^{1,2}$, Huarui Gong ${ }^{1,2} \mathbb{D}$ and \\ Zhu Ouyang 1,3,*
}

1 Yucheng Comprehensive Experiment Station, Key Laboratory of Ecosystem Network Observation and Modeling, Institute of Geographic Sciences and Natural Resources Research, Chinese Academy of Sciences, Beijing 100101, China; liangrubiao@outlook.com (R.L.); hourx@igsnrr.ac.cn (R.H.); jingli@igsnrr.ac.cn (J.L.); yun.lv@foxmail.com (Y.L.); hang_some@126.com (S.H.); gonghr.18b@igsnrr.ac.cn (H.G.)

2 University of Chinese Academy of Sciences, Beijing 100049, China

3 CAS Engineering Laboratory for Yellow River Delta Modern Agriculture, Institute of Geographic Sciences and Natural Resources Research, CAS, Beijing 100101, China

* Correspondence: ouyz@igsnrr.ac.cn; Tel.: +86-10-6485-6514

Received: 5 November 2019; Accepted: 7 January 2020; Published: 9 January 2020

\begin{abstract}
The application of bioorganic fertilizer affects rhizosphere microbes and further improves soil fertility in farmlands. However, the effects of different fertilizers on rhizosphere bacterial community diversity and structure of winter wheat remains unclear. In this study, we explored the effects of different fertilization treatments (no fertilizer added, CK; nitrogen fertilizer, NF; bioorganic fertilizer, BOF) on the rhizosphere bacterial community of winter wheat in the North China Plain. Rhizosphere soil treated with BOF had a higher Shannon index than that of CK and NF. The relative abundance of the Proteobacteria treated with BOF was significantly higher than that of NF, while the Acidobacteria and Planctomycetes were significantly lower. The redundancy analysis (RDA) and Mantel test showed that soil bacterial communities were significantly correlated with $\mathrm{pH}$, nitrate, available phosphorus (AP), and available potassium (AK). Our findings indicated that BOF increased bacterial diversity and the relative abundance of copiotrophic bacteria in rhizosphere soil, while NF reduced bacterial diversity and increased the relative abundance of oligotrophic bacteria. The increase in copiotrophic bacteria in the rhizosphere of winter wheat could indicate an increase in soil nutrient availability, which might have positive implications for soil fertility and crop production.
\end{abstract}

Keywords: fertilization treatment; bacterial communities; rhizosphere; North China plain; illumina high-throughput sequencing

\section{Introduction}

Microorganisms play an important role in maintaining soil fertility and ecosystem function [1,2]. The rhizosphere is the area in the soil that is immediately adjacent to and affected by the roots of the plant [3]. The roots of the plant secrete a large amount of carbon-containing organic material into the soil, which is the carbon source, nitrogen source, and energy required for the growth and reproduction of soil microorganisms. A large number of microbes accumulate around the roots of plants [4], resulting in a distinction between the soil nutrient environment and soil microbial community structure in the non-rhizosphere [5]. The rhizosphere becomes the region with the strongest interaction between plant roots, soil, and microorganisms [6]. Rhizosphere microbes become an important medium between plant roots and soil, playing a significant role in the soil material cycle and energy flow $[7,8]$. 
The application of fertilizer is an important management measure in agricultural production, which has the effect of promoting crop growth and increasing yield $[9,10]$, and it also affects soil microbes [11,12]. Currently, the extensive use of chemical fertilizers leads to a decrease in soil fertility and a series of environmental problems [13-15], while bioorganic fertilizer not only increases soil fertility through the input of beneficial microorganisms and organic materials [16,17] but also prevents many of the environmental problems caused by chemical fertilizers. Studies have shown that different fertilization treatments have a significant impact on soil microbial biomass and community structure [18-21], but rhizosphere microbes and bulk microbes are not been differentiated in these studies. Thus, it is necessary to investigate the microbial community in rhizosphere soil [22].

In this study, we conducted a pot experiment using winter wheat to investigate the effects of different fertilizer treatments on bacterial community diversity and structure in rhizosphere soil, and to determine which soil properties are important factors affecting bacterial communities. Understanding the response of rhizosphere microorganisms to different fertilization treatments will assist with providing a theoretical basis for scientific, rational, and effective fertilization strategies, which in turn will improve soil fertility and productivity and reduce the waste of fertilizer resources.

\section{Materials and Methods}

\subsection{Site Description}

The experimental field is located at the Yucheng Comprehensive Experiment Station of Chinese Academy of Sciences $\left(36^{\circ} 50^{\prime} \mathrm{N}, 116^{\circ} 34^{\prime} \mathrm{E}\right)$. The station is located in Yucheng City, Shandong Province, and is located in the North China Plain of the alluvial plain in the lower reaches of the Yellow River, at an average altitude of $20 \mathrm{~m}$. The climate is warm-temperate and sub-humid monsoon climate with an average annual precipitation of $593 \mathrm{~mm}$, an average temperature of $13.1^{\circ} \mathrm{C}$, and a frost-free period of 220 days. The soil is calcaric fluvisols according to the FAO-UNESCO system. Soil texture is silt loam with $12 \%$ sand, $66 \%$ silt, and $22 \%$ clay. The crop planting system is a twice-yearly rotation of winter wheat and summer maize.

\subsection{Experimental Design and Soil Sampling}

Three treatments were established in the experiment: (1) control, with no fertilizer added, CK; (2) nitrogen fertilizer (urea; $46 \% \mathrm{~N}$ ) added, NF; and (3) bioorganic fertilizer (1.78\% N; produced by ETS, Biological Technology Development Co., Ltd., Tianjin, China) added, BOF. Three replicates (pots) were conducted for each treatment. All fertilizer treatments received the same total amount of $\mathrm{N}$ addition at a rate of $200 \mathrm{~kg} \mathrm{~N} \mathrm{ha}^{-1}$, which reflected the total nitrogen input in a growing season of farmland crops in the North China Plain. The NF treatment received $3.07 \mathrm{~g}$ urea per pot, and the BOF treatment received $79.38 \mathrm{~g}$ bioorganic fertilizer per pot. Fifty percent of the nitrogen fertilizer and $100 \%$ of the bioorganic fertilizer were applied as the base fertilizers in the different treatments, and the remaining nitrogen fertilizer was applied during the returning green stage. Soil samples were collected from the top $20 \mathrm{~cm}$ of a field, and after air-drying, were passed through a $2 \mathrm{~mm}$ sieve for later use. The size of pots used in the experiment was $30 \mathrm{~cm}$ in diameter and $23 \mathrm{~cm}$ in height. A total of $20 \mathrm{~kg}$ of soil was packed into each pot. The soil water content was adjusted to $65 \%$ of the field water holding capacity. In each pot, 46 wheat seeds were sown in two rows. In order to ensure that the environmental conditions were similar to those in the field, the soil-filled pots were buried in the field soil.

The experiment began in October 2016 and samples were collected in May 2017. When sampling, the root system of the whole potted plants were removed from the pots, and the roots were tapped to loosen the soil. The soil attached to the surface of the roots was collected using a sterile brush, and known as the rhizosphere soil sample (R). The soil collected from the rootless area next to the plant root system was called the bulk soil sample (B). The collected soil samples were passed through a $2 \mathrm{~mm}$ sieve to remove plant debris and other impurities from the roots. Some soil samples were air-dried for 
analyzing soil properties; some were stored at a $-20{ }^{\circ} \mathrm{C}$ for measuring soil microbial biomass; others were stored at $-80^{\circ} \mathrm{C}$ for determining soil bacterial communities.

\subsection{Measurement of Soil Properties and Soil Microbial Biomass}

The soil $\mathrm{pH}$ value was determined by potentiometry. Soil water content was determined by the drying method. Soil organic matter (SOM) was determined by the external heating method with potassium dichromate $\left(\mathrm{K}_{2} \mathrm{Cr}_{2} \mathrm{O}_{7}\right)$. Soil total nitrogen (TN) was determined by the semi-micro Kjeldahl digestion method. Ammonium nitrogen in the soil was determined by the indophenol blue colorimetric method. Nitrate was determined by dual-wavelength ultraviolet spectrophotometry. Available phosphorus (AP) was determined by the molybdenum anti-colorimetric method. Available potassium (AK) was determined by ammonium acetate extraction-flame spectrophotometry. Microbial biomass carbon and nitrogen (MBC; MBN) were determined by the chloroform fumigation method [23,24].

\subsection{DNA Extraction and Amplicon Sequencing}

Soil total DNA was extracted using the PowerSoil DNA Extraction Kit (MoBio Laboratories Inc., Carlsbad, CA, USA). The V4 region gene fragment was amplified using primer 515F (GTGCCAGCMGCCGCGGTAA) and 806R (GGACTACHVGGGTWTCTAAT). The modified primers contain different Barcodes to distinguish between different samples. The polymerase chain reaction (PCR) volume was $50 \mu \mathrm{L}$, which included ddH $\mathrm{O}_{2} \mathrm{O} 23 \mu \mathrm{L}$, Premix Taq DNA polymerase $25 \mu \mathrm{L}$, DNA template amount $1 \mu \mathrm{L}(5-10 \mathrm{ng})$, forward primer $0.5 \mu \mathrm{L}\left(20 \mathrm{ng} \mu \mathrm{L}^{-1}\right)$, and forward primer $0.5 \mu \mathrm{L}$ (20 ng $\left.\mu \mathrm{L}^{-1}\right)$. The PCR amplification reaction conditions were: $95{ }^{\circ} \mathrm{C}, 5 \mathrm{~min} ; 30 \times\left(94{ }^{\circ} \mathrm{C}, 45 \mathrm{~s} ; 56{ }^{\circ} \mathrm{C}\right.$, $\left.45 \mathrm{~s} ; 72{ }^{\circ} \mathrm{C}, 45 \mathrm{~s}\right) ; 72{ }^{\circ} \mathrm{C}, 10 \mathrm{~min}$. Each sample was amplified three times. After PCR amplification, three tubes of the same sample were combined, purified using the GeneJET kit (Thermo Scientific Inc., Waltham, MA, USA), and the PCR product concentration was determined using NanoDrop 2000 (Thermo Scientific Inc., Waltham, MA, USA). PCR products were detected by electrophoresis with $2 \%$ agarose gel. The PCR products were mixed at the same volume according to the concentration of the PCR products. After thoroughly mixing, 2\% agarose gel electrophoresis was used to detect the PCR products. The gel recovery kit (Qiagen, Hilden, Germany) was used to recover the products for the target band. The library was constructed using the TruSeq ${ }^{\circledR}$ DNA PCR-Free Sample Preparation Kit (Illumina, San Diego, CA, USA). The constructed library was quantified by Qubit and Q-PCR. After the library was qualified, it was sequenced using the Illumina HiSeq2500 platform (Novogene Bioinformatics Technology Co., Ltd., Beijing, China).

\subsection{Biological Information Analysis and Data Processing}

The sample data were resolved according to the Barcode sequence and the PCR amplification primer sequence, and each sample was spliced using FLASH (version 1.2.7) after truncating the Barcode and primer sequences [25]. Data processing was performed using Qiime (version 1.9.1) [26]. All valid sequences of all samples were clustered using Uparse (version 7.0.1001) [27], and the sequences were clustered into operational taxonomic units (OTUs) by default with $97 \%$ identity. Species annotation of OTUs representative sequences was determined by species annotation analysis using the Mothur method and SILVA SSU rRNA database [28,29]. Fast multi-sequence alignments were performed using MUSCLE (version 3.8.31) to obtain phylogenetic relationships for all OTUs representative sequences [30]. Finally, the data of each sample was homogenized, according to the minimum amount of data in the sample. All sequences obtained in this study had been registered in the NCBI's Sequence Read Archive database (accession numbers: SRR10362754-SRR10362771).

\subsection{Statistical Analysis}

The Observed species, Chao1, Shannon, Simpson, and abundance-based coverage estimator (ACE) indices were calculated using Qiime software (version 1.9.1). Soil properties, microbial biomass, and soil bacterial alpha diversity index of different fertilization treatments were compared by one-way ANOVA 
using SPSS software (version 20.0). Pearson correlation analysis of soil bacterial alpha diversity index and soil properties was calculated using SPSS software. Ade4 data package and ggplot2 data package of R software (version 2.15.3) were used for the principal component analysis (PCA). The Mothur software (version 1.30.1) was used for analysis of molecular variance (AMOVA). Species composition analysis of significant differences between groups was performed by R software for the T- test. Vegan data package of $\mathrm{R}$ software was used to conduct a redundancy analysis (RDA) and Mantel test of bacterial community structure.

\section{Results}

\subsection{Effects of Different Fertilizers on Soil Properties and Microbial Biomass}

Compared to the control, the $\mathrm{pH}$ of the rhizosphere and bulk soil increased significantly in $\mathrm{BOF}$, while NF did not change (Table 1). There was no significant effect on SOM and TN in the rhizosphere and bulk soil in BOF, while soil TN increased in NF. Both the BOF and NF treatments had no effect on soil ammonium. The concentration of nitrate in the rhizosphere and bulk soil was the lowest in BOF and was significantly lower in rhizosphere soil than that in CK and NF. The concentration of AP and AK increased in the rhizosphere soil in BOF. The AP concentration increased by $66.14 \%$ in comparison to both CK and NF treatment, and AK increased by $12.50 \%$ and $27.35 \%$, respectively. The nitrate in the rhizosphere soil of each treatment was lower than that in the bulk soil, which may be related to the large amount of nitrate absorption in the rhizosphere of the winter wheat roots. The other soil properties were higher in the rhizosphere than in the bulk soil (except for AP in the NF treatment).

MBC was the highest in the rhizosphere and non-rhizosphere in NF, followed by BOF, both of which were higher than CK. MBN in the rhizosphere and bulk soil was lower in NF and BOF than that in CK. Rhizosphere MBC and MBN content were higher than those in non-rhizosphere soil.

Table 1. Effects of different fertilizer treatments on soil properties and microbial biomass (mean \pm SD).

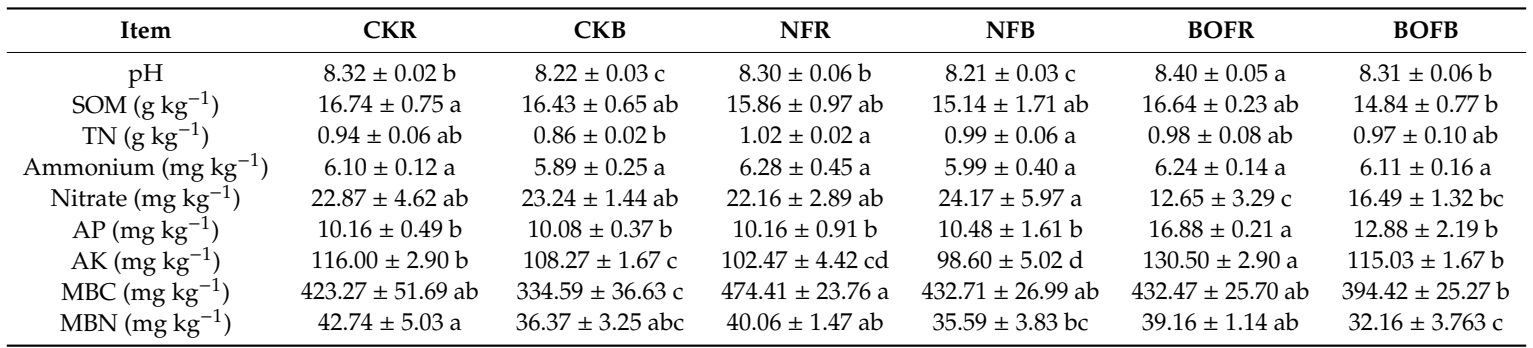

Note: Different lowercase letters mean indicate significant differences among different treatments at $p<0.05 . \mathrm{SOM}$, soil organic matter; $\mathrm{TN}$, total nitrogen; $\mathrm{AP}$, available phosphorus; $\mathrm{AK}$, available potassium; $\mathrm{MBC}$, microbial biomass carbon; MBN, microbial biomass nitrogen; CKR, rhizosphere of no fertilizer; CKB, bulk of no fertilizer; NFR, rhizosphere of nitrogen fertilizer; NFB, bulk of nitrogen fertilizer; BOFR, rhizosphere of bioorganic fertilizer; BOFB, bulk of bioorganic fertilizer.

\subsection{Effects of Different Fertilizers on Soil Bacteria Diversity Index}

High-throughput sequencing results showed 739,971 effective sequences obtained from all samples, and 3562-3853 OTUs obtained after clustering. Compared with CK and NF, the Shannon diversity index for rhizosphere soil treated with BOF was the highest, which increased by $0.79 \%$ and $1.60 \%$, respectively, while the Shannon diversity index for rhizosphere soil treated with NF was the lowest (Table 2). The Simpson, Chao1, and ACE indices did not differ between treatments. In addition, there was no significant difference in the bacterial diversity index between rhizosphere and non-rhizosphere soil in each treatment. The Observed Species Index was the significant positive correlation between with soil $\mathrm{pH}$ and $\mathrm{AK}$ and was significantly negatively correlated with nitrate. The Shannon index was significantly positively correlated with soil $\mathrm{pH}, \mathrm{AP}$, and AK and significantly negatively correlated with nitrate. Both the Chao1 and ACE indices were significantly positively correlated with pH (Table 3). 
Table 2. Effects of different fertilizer treatments on soil bacterial alpha diversity index (mean \pm SD).

\begin{tabular}{cccccc}
\hline Treatment & Observed Species & Shannon & Simpson & Chao1 & ACE \\
\hline CKR & $3853 \pm 47 \mathrm{a}$ & $10.09 \pm 0.07 \mathrm{ab}$ & $0.998 \pm 0.001 \mathrm{a}$ & $5141.34 \pm 245.51 \mathrm{a}$ & $5270.75 \pm 185.09 \mathrm{a}$ \\
CKB & $3652 \pm 191 \mathrm{a}$ & $10.05 \pm 0.03 \mathrm{ab}$ & $0.998 \pm 0.001 \mathrm{a}$ & $4696.15 \pm 650.13 \mathrm{a}$ & $4712.37 \pm 605.82 \mathrm{a}$ \\
NFR & $3692 \pm 94 \mathrm{a}$ & $10.01 \pm 0.07 \mathrm{~b}$ & $0.997 \pm 0.001 \mathrm{a}$ & $4838.85 \pm 65.13 \mathrm{a}$ & $4941.59 \pm 10.71 \mathrm{a}$ \\
NFB & $3562 \pm 238 \mathrm{a}$ & $10.06 \pm 0.06 \mathrm{ab}$ & $0.998 \pm 0.001 \mathrm{a}$ & $4302.26 \pm 614.79 \mathrm{a}$ & $4399.41 \pm 588.79 \mathrm{a}$ \\
BOFR & $3853 \pm 130 \mathrm{a}$ & $10.17 \pm 0.09 \mathrm{a}$ & $0.998 \pm 0.001 \mathrm{a}$ & $5032.43 \pm 335.56 \mathrm{a}$ & $5084.55 \pm 337.89 \mathrm{a}$ \\
BOFB & $3838 \pm 244 \mathrm{a}$ & $10.16 \pm 0.10 \mathrm{a}$ & $0.998 \pm 0.000 \mathrm{a}$ & $4803.29 \pm 599.45 \mathrm{a}$ & $4934.92 \pm 602.96 \mathrm{a}$ \\
\hline
\end{tabular}

Note: Different lowercase letters mean indicate significant differences among different treatments at $p<0.05$. ACE, abundance-based coverage estimator; CKR, rhizosphere of no fertilizer; CKB, bulk of no fertilizer; NFR, rhizosphere of nitrogen fertilizer; NFB, bulk of nitrogen fertilizer; BOFR, rhizosphere of bioorganic fertilizer; BOFB, bulk of bioorganic fertilizer.

Table 3. Pearson correlation coefficients between the alpha diversity index of the soil bacterial community and soil properties.

\begin{tabular}{cccccc}
\hline Item & Observed Species & Shannon & Simpson & Chao1 & ACE \\
\hline pH & $0.756^{* *}$ & $0.619^{* *}$ & 0.172 & $0.652^{* *}$ & $0.687^{* *}$ \\
SOM & -0.062 & -0.121 & -0.259 & 0.101 & 0.075 \\
TN & 0.004 & 0.152 & 0.010 & -0.027 & 0.018 \\
Ammonium & 0.094 & 0.220 & -0.029 & -0.023 & 0.034 \\
Nitrate & $-0.560^{*}$ & $-0.730^{* *}$ & -0.463 & -0.418 & -0.410 \\
AP & 0.354 & $0.616^{* *}$ & 0.180 & 0.239 & 0.218 \\
AK & $0.544^{*}$ & $0.601^{* *}$ & 0.169 & 0.440 & 0.426 \\
\hline
\end{tabular}

Note: ${ }^{*} p<0.05$; ${ }^{* *} p<0.01$. ACE, abundance-based coverage estimator; $\mathrm{SOM}$, soil organic matter; $\mathrm{TN}$, total nitrogen; $\mathrm{AP}$, available phosphorus; $\mathrm{AK}$, available potassium.

\subsection{Effects of Different Fertilizers on Soil Bacterial Community Structure}

Sequencing results showed a total of 43 phyla, including Proteobacteria $(29.67 \%-34.15 \%)$, Acidobacteria (14.24\%-19.08\%), Actinobacteria (11.01\%-12.78\%), Bacteroidetes $(7.41 \%-9.10 \%)$ and Thaumarchaeota (3.90\%-5.30\%) as the main dominant groups (Figure 1a). At the order level, relatively high abundance groups were Xanthomonadales $(4.52 \%-5.49 \%)$, Sphingomonadales $(3.17 \%-4.75 \%)$, and Sphingobacteriales (3.73\%-4.94\%), Rhodospirillales (3.63\%-4.88\%) (Figure $1 \mathrm{~b})$.
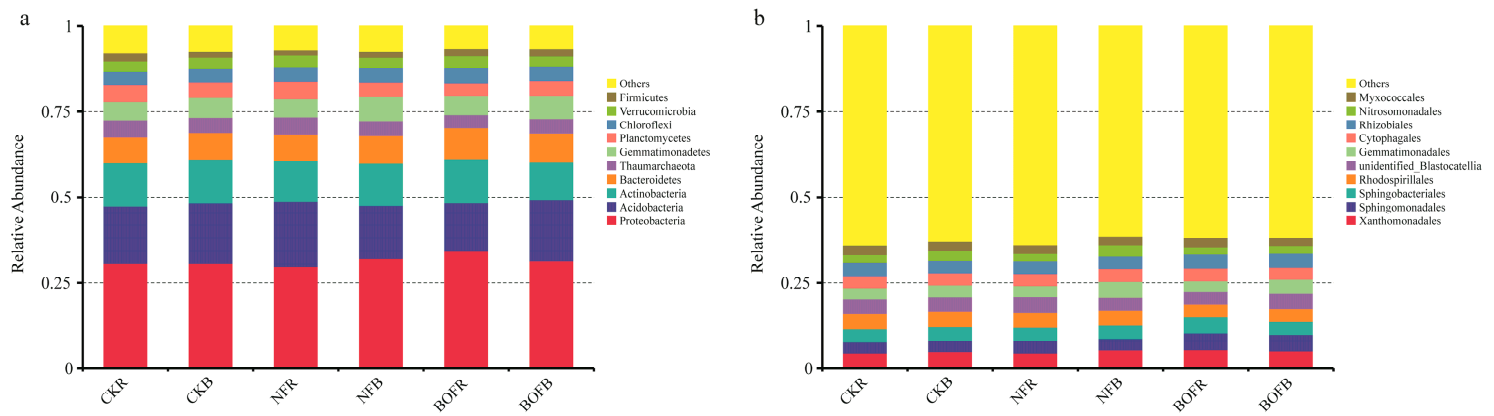

Figure 1. Bacterial community composition at the (a) phylum level and (b) order level in different fertilization treatments. CKR, rhizosphere of no fertilizer; $C K B$, bulk of no fertilizer; NFR, rhizosphere of nitrogen fertilizer; NFB, bulk of nitrogen fertilizer; BOFR, rhizosphere of bioorganic fertilizer; BOFB, bulk of bioorganic fertilizer.

The PCA showed that soil bacterial structure differed under the different treatments. While the CK and NF treatments clustered together (and thus similar), the BOF treatment was clearly separated and therefore different from the other two treatments (Figure 2). There were some differences between the rhizosphere and bulk soil. In addition, the results of the AMOVA indicated that there was a significant difference in bacterial community structure between the different fertilization treatments $(p<0.001)$. 


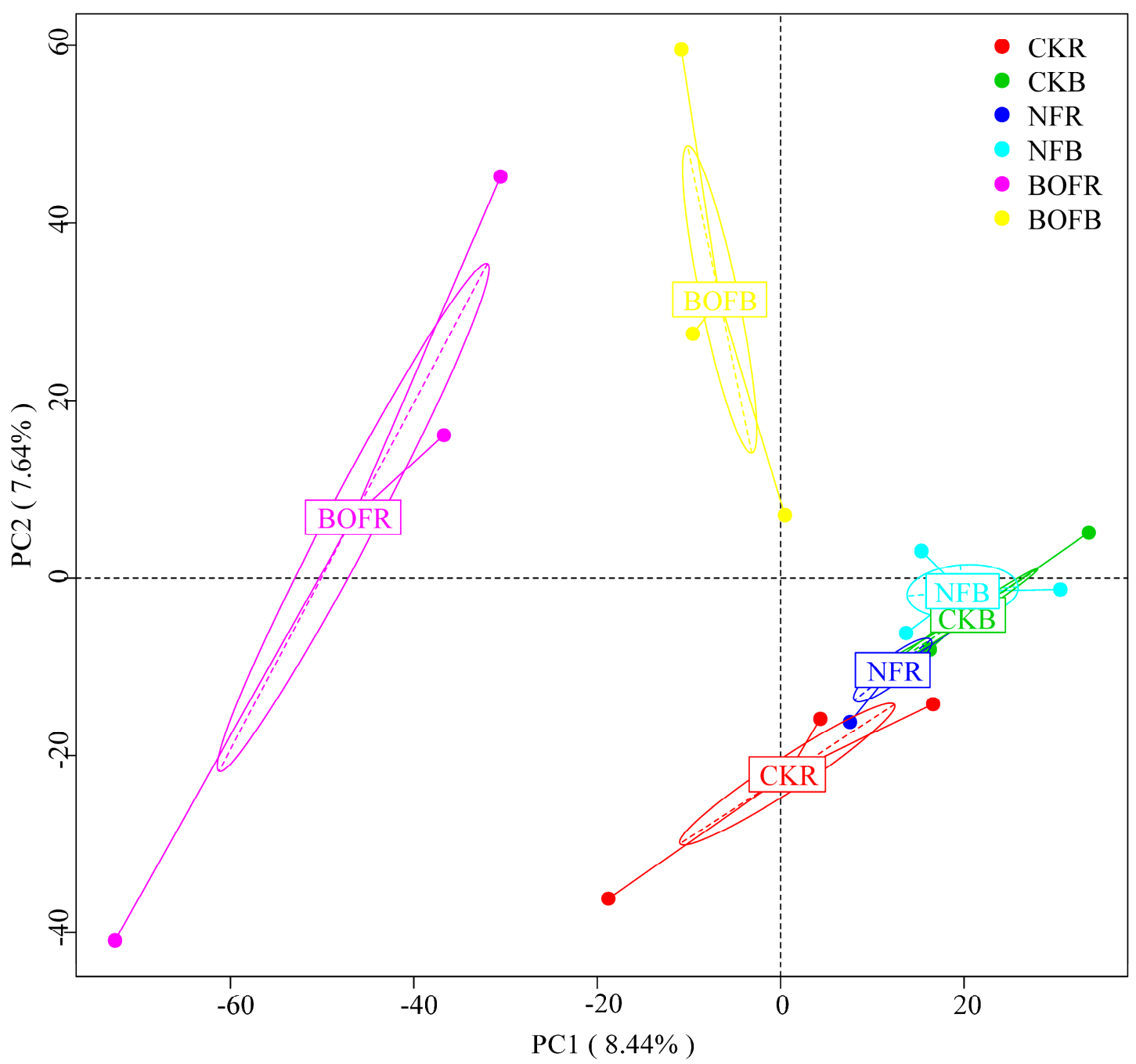

Figure 2. Principal components analysis of bacterial community structure in different fertilization treatments. CKR, rhizosphere of no fertilizer; $C K B$, bulk of no fertilizer; NFR, rhizosphere of nitrogen fertilizer; NFB, bulk of nitrogen fertilizer; BOFR, rhizosphere of bioorganic fertilizer; BOFB, bulk of bioorganic fertilizer.

Based on the analysis of soil bacterial community structure, we analyzed the effects of the different treatments on soil bacterial species. As shown in Figure 3a,b, we compared the bacterial species composition in rhizosphere soil treated with NF and BOF at the phylum and order level. The relative abundance of Proteobacteria in the BOF treatment was significantly higher than that in NF, while the relative abundance of Acidobacteria and Planctomycetes was significantly lower than NF. For the order level, the relative abundance of Sphingomonadales and Sphingobacteriales in the BOF treatment was significantly higher than that in the NF treatment.

\subsection{Correlation between Bacterial Community and Soil Properties}

The changes in soil bacterial community structure were related to soil properties. We used the envfit function to screen out four soil properties that best reflect the changes in soil bacterial community structure, and conducted RDA on the screened soil properties and bacterial community structure. The results showed that the soil bacterial community was significantly correlated with soil $\mathrm{pH}(p<0.01)$, nitrate $(p<0.01), \operatorname{AP}(p<0.01)$, and AK $(p<0.05)$ (Figure 4). Similarly, the Mantel test showed that soil $\mathrm{pH}(p<0.05)$, nitrate $(p<0.01), \operatorname{AP}(p<0.01)$, and AK $(p<0.01)$ were important factors affecting soil bacterial community. 
a

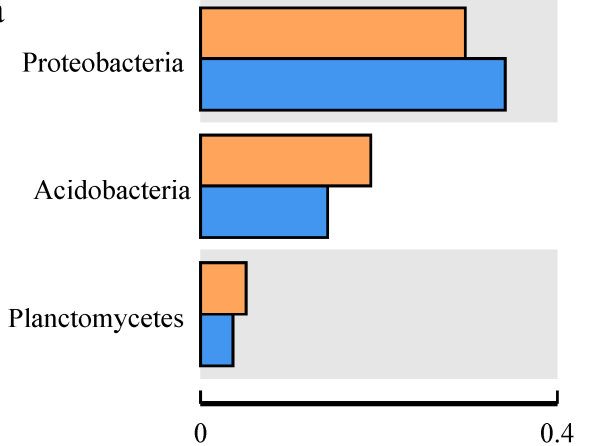

$\square$ NFR $\square$ BOFR b

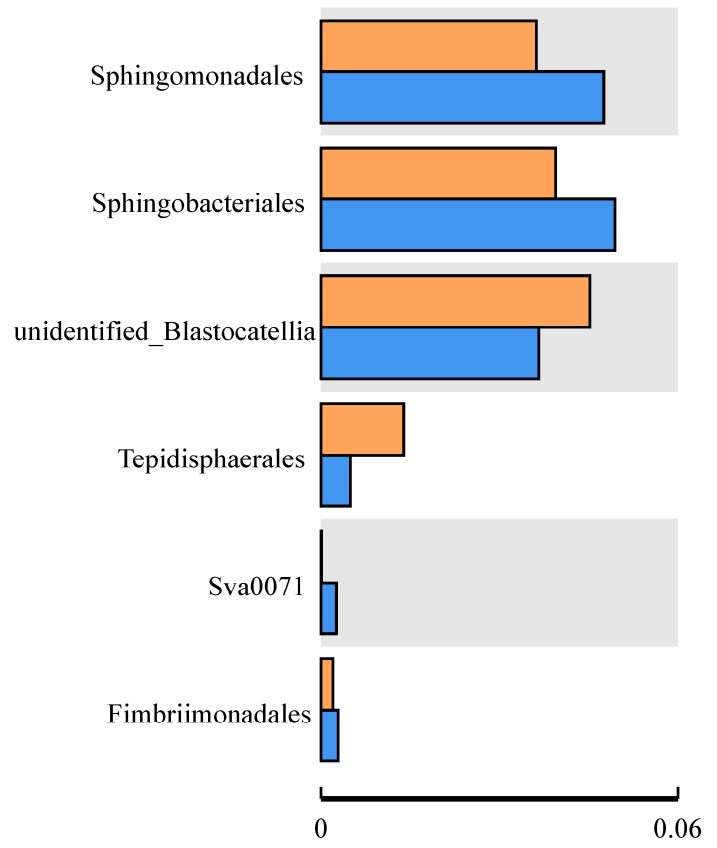

Figure 3. T-test analysis of bacterial community structure at the (a) phylum level and (b) order level between NFR and BOFR. NFR, rhizosphere of nitrogen fertilizer; BOFR, rhizosphere of bioorganic fertilizer.

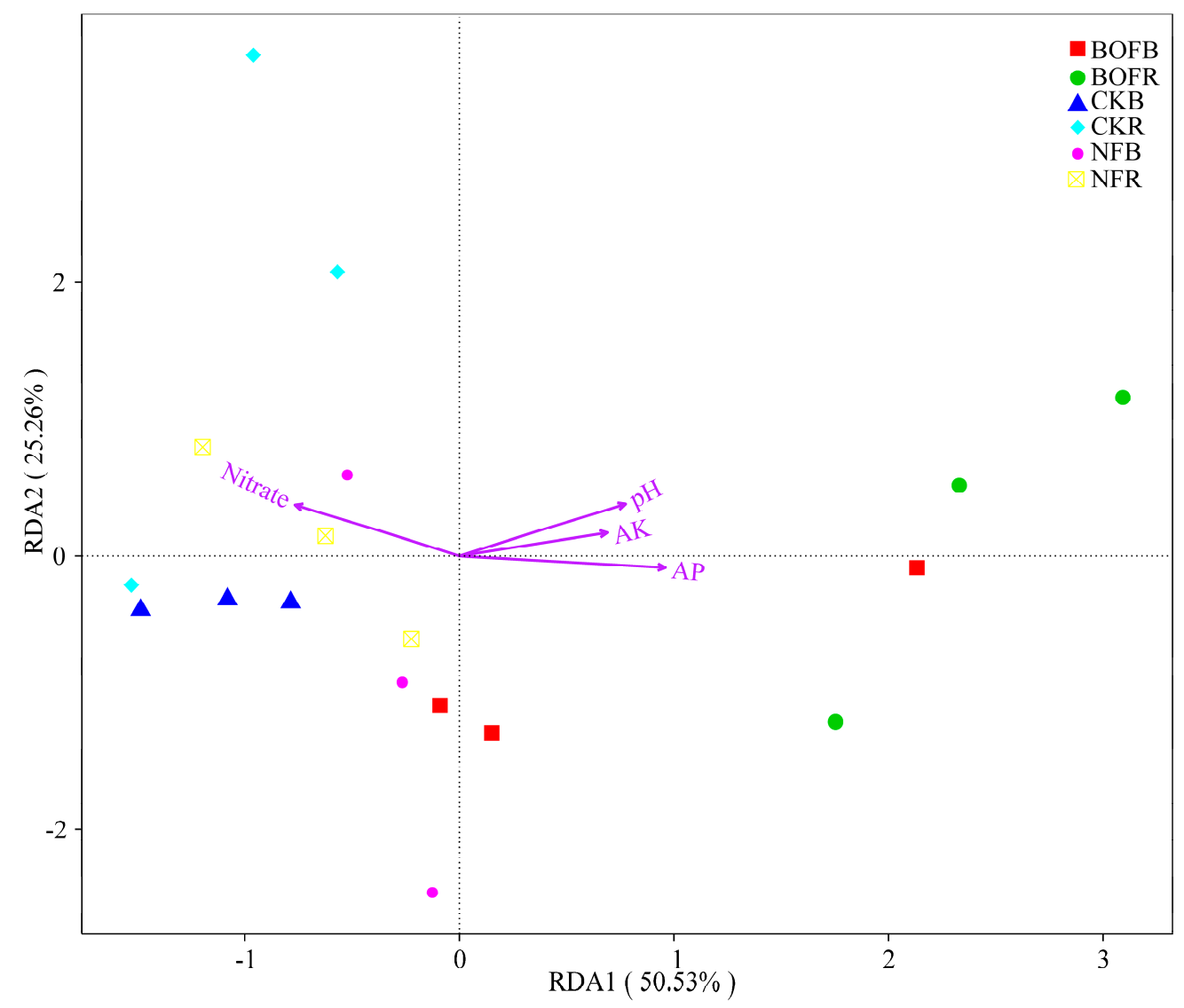

Figure 4. Redundancy analysis of bacterial community structure and soil properties. AP, available phosphorus; AK, available potassium; CKR, rhizosphere of no fertilizer; $\mathrm{CKB}$, bulk of no fertilizer; NFR, rhizosphere of nitrogen fertilizer; NFB, bulk of nitrogen fertilizer; BOFR, rhizosphere of bioorganic fertilizer; BOFB, bulk of bioorganic fertilizer. 


\section{Discussion}

The diversity index is an important indicator for evaluating the diversity of bacterial communities. The higher the diversity index the higher the richness and diversity. Studies have shown that different fertilization treatments have different effects on soil bacterial community diversity and that chemical fertilizers lead to reduced community diversity [31-33], while organic fertilizers could increase bacterial community diversity $[11,34,35]$. Similar results were obtained in the present study. The Shannon index was the highest for the BOF treatment, regardless of whether the soil was from the rhizosphere or non-rhizosphere (Table 2). In the rhizosphere, the Shannon index for the BOF treatment was higher than that of $\mathrm{CK}$, while the NF treatment was lower than $\mathrm{CK}$, indicating that bacterial diversity in the rhizosphere increased under BOF, but decreased under NF. This may be due to two reasons: Firstly, the bioorganic fertilizer itself contains microorganisms [14,36], while the nitrogen fertilizer does not. These microorganisms enter the soil with the application of BOF, which increases the bacterial diversity in the soil. Secondly, the bioorganic fertilizer contains a large amount of organic matter that can be absorbed and utilized by soil microorganisms, thereby promoting the growth and development of bacteria $[37,38]$. These substances are not present in nitrogen fertilizer. In addition, the soil alpha diversity index was significantly correlated with soil $\mathrm{pH}$, nitrate, $\mathrm{AP}$, and $\mathrm{AK}$, indicating that soil $\mathrm{pH}$, nitrate, $\mathrm{AP}$, and $\mathrm{AK}$ were important factors affecting the diversity of bacterial communities.

Bacteria is an important part of soil microbes. They participate in soil nutrient cycling and play a significant role in maintaining the stability of the entire soil ecosystem [39]. Studies have shown that the majority of the dominant soil bacteria are similar, which includes about 10 bacterial groups [40,41]. Ai et al. [42] showed that the relative abundance of Proteobacteria in the rhizosphere soil of wheat was the highest. Wang et al. [22] found that Proteobacteria, Chloroflexi, Acidobacteria, and Actinobacteria were the dominant bacterial groups in the wheat-rice rotation system. The results of the present study showed that the dominant bacterial phyla and orders in the rhizosphere and bulk soil were similar (Figure 1a,b), but the relative abundances were significantly different (Figure 3a,b). The dominant phyla in the rhizosphere and non-rhizosphere of each treatment were Proteobacteria, Acidobacteria, Actinobacteria, Bacteroidetes, and Thaumarchaeota. The dominant orders were Xanthomonadales, Sphingomonadales, Sphingobacteriales, and Rhodospirillales.

Previous studies have shown that the dominant groups of bacteria in farmland soils are similar, but their relative abundance is affected by soil type or texture and crop varieties [43-45]. In the present study, different fertilization treatments changed the soil properties of the rhizosphere (Table 1) and therefore affected the relative abundance of the dominant bacterial groups. Our results showed that the relative abundance of rhizosphere Proteobacteria treated with bioorganic fertilizer was significantly higher than that treated with nitrogen fertilizer while Acidobacteria was significantly lower (Figure 3a). Studies have shown that Proteobacteria are copiotrophic bacteria, and Acidobacteria are oligotrophic bacteria [46,47]. Thus, our findings indicated that the BOF treatment increased the relative abundance of copiotrophic bacteria while the NF treatment increased the relative abundance of oligotrophic bacteria. Because bioorganic fertilizer contains exogenous microorganisms and organic matter, nutrient availability in the rhizosphere increases, providing a suitable environment for the growth of copiotrophic bacteria, while nitrogen fertilizer does not contain exogenous microorganisms and organic matter, and this is coupled with long-term nitrogen fertilization in this region. A large amount of the application of nitrogen fertilizer results in low soil nutrient availability, which is beneficial to the growth of oligotrophic bacteria. Additionally, we determined the bacterial communities of the bioorganic fertilizer used in this study. The results showed that Proteobacteria was the dominant phylum. This might be another reason why the relative abundance of Proteobacteria in the BOF treatment was higher than that in the NF treatment.

The relative abundance of Sphingomonadales and Sphingobacteriales in the rhizosphere of the BOF treatment was significantly higher than that of the NF treatment (Figure 3b). Sphingomonadales and Sphingobacteriales belong to Proteobacteria and Bacteroidetes, respectively. Both Proteobacteria and Bacteroidetes are copiotrophic bacteria. This further illustrated that the bioorganic fertilizer increased 
the abundance of copiotrophic bacteria. Eichorst and Kuske [48] showed that Sphingobacteriales are copiotrophic microbes that live in a highly carbon-efficient environment that has the ability to break down cellulose and chitin while also degrading nitrogen-containing substances. Lopes et al. [49] found that Sphingomonadales are involved in the degradation of cellulose and lignin. These two microorganisms may have promoted the decomposition of soil organic matter in the rhizosphere environment of the BOF treatment, which would increase nutrient availability for crop absorption and utilization. We considered that this might be the reason why the bioorganic fertilizer improved nutrient availability in rhizosphere soil and increased winter wheat yield.

Different fertilizer applications changes the physical and chemical properties of the soil, which in turn affects the soil bacterial community structure [50,51]. Previous studies have found that $\mathrm{pH}$, nitrate, and AP were important factors in soil affecting microbial community structure [52-54]. Consistent with the previous studies, the present study found that the bacterial community structure in soil under different fertilization treatments was significantly correlated with soil $\mathrm{pH}$, nitrate, $\mathrm{AP}$, and AK (Figure 4). This may explain the changes in bacterial community structure under different fertilization treatments. The concentrations of soil nitrate, AP, and AK represent soil nutrient availability, which affects the soil bacterial community structure. Our findings showed that the bioorganic fertilizer improved nutrient availability in rhizosphere soil, which promoted the growth of copiotrophic bacteria, while nitrogen fertilizer reduced nutrient availability, which was more conducive to the growth of oligotrophic bacteria.

Different fertilization treatments affected bacterial community diversity and structure in rhizosphere soil. This study only analyzed the overall changes in the bacterial community in rhizosphere soil and did not study microbes with special functions. These microorganisms are involved in important soil metabolic pathways. Therefore, whether the differences in the functional microbial diversity and structural caused by different fertilization treatments lead to soil fertility and ecosystem function changes need to be investigated.

\section{Conclusions}

The BOF treatment increased the bacterial diversity in rhizosphere soil of winter wheat in the North China Plain, while the NF treatment reduced bacterial diversity. Bioorganic fertilizers increased the relative abundance of copiotrophic bacteria in the rhizosphere, while nitrogen fertilizer increased the relative abundance of oligotrophic bacteria. Soil $\mathrm{pH}$, nitrate, $\mathrm{AP}$, and $\mathrm{AK}$ were important factors affecting the bacterial communities of rhizosphere soil.

Author Contributions: R.L. and Z.O. designed the experiments; R.L., R.H., J.L., Y.L., S.H., and H.G. performed the research and analyzed the data; R.L. wrote the paper. All authors have read and agreed to the published version of the manuscript.

Funding: This work was supported by the Science and Technology Service Network Initiative (STS) of the Chinese Academy of Sciences (KFJ-STS-ZDTP-049), the Strategic Priority Research Program of the Chinese Academy of Sciences (XDA23050103) and the National Key Research and Development Program of China (2016YFD0300808).

Acknowledgments: We thank the staff of Yucheng Comprehensive Experiment Station of the Chinese Academy of Sciences for field and lab assistance. We also thank the editors and anonymous reviewers for their constructive comments in the improvement of this manuscript.

Conflicts of Interest: The authors declare no conflict of interest.

\section{References}

1. Falkowski, P.G.; Tom, F.; Delong, E.F. The microbial engines that drive Earth's biogeochemical cycles. Science 2008, 320, 1034-1039. [CrossRef] [PubMed]

2. Nie, Y.; Wang, M.; Zhang, W.; Ni, Z.; Hashidoko, Y.; Shen, W. Ammonium nitrogen content is a dominant predictor of bacterial community composition in an acidic forest soil with exogenous nitrogen enrichment. Sci. Total Environ. 2017, 624, 407-415. [CrossRef] [PubMed]

3. Venturi, V.; Keel, C. Signaling in the Rhizosphere. Trends Plant Sci. 2016, 21, 187-198. [CrossRef] [PubMed] 
4. Raaijmakers, J.M.; Paulitz, T.C.; Steinberg, C.; Alabouvette, C.; Moënne-Loccoz, Y. The rhizosphere: A playground and battlefield for soilborne pathogens and beneficial microorganisms. Plant Soil 2009, 321, 341-361. [CrossRef]

5. Phillips, R.P.; Bernhardt, E.S.; Schlesinger, W.H. Elevated $\mathrm{CO}_{2}$ increases root exudation from loblolly pine (Pinus taeda) seedlings as an N-mediated response. Tree Physiol. 2009, 29, 1513-1523. [CrossRef]

6. Harsh Pal, B.; Sang-Wook, P.; Weir, T.L.; Callaway, R.M.; Vivanco, J.M. How plants communicate using the underground information superhighway. Trends Plant Sci. 2004, 9, 26-32.

7. Gabriele, B.; Kornelia, S. Plant species and soil type cooperatively shape the structure and function of microbial communities in the rhizosphere. FEMS Microbiol. Ecol. 2010, 68, 1-13.

8. Wardle, D.A.; Bardgett, R.D.; Klironomos, J.N.; Heikki, S.L.; van der Putten, W.H.; Wall, D.H. Ecological linkages between aboveground and belowground biota. Science 2004, 304, 1629-1633. [CrossRef]

9. Shang, Q.; Ling, N.; Feng, X.; Yang, X.; Wu, P.; Zou, J.; Shen, Q.; Guo, S. Soil fertility and its significance to crop productivity and sustainability in typical agroecosystem: A summary of long-term fertilizer experiments in China. Plant Soil 2014, 381, 13-23. [CrossRef]

10. Yu, H.; Ling, N.; Wang, T.; Zhu, C.; Wang, Y.; Wang, S.; Gao, Q. Responses of soil biological traits and bacterial communities to nitrogen fertilization mediate maize yields across three soil types. Soil Tillage Res. 2019, 185, 61-69. [CrossRef]

11. Berthrong, S.T.; Buckley, D.H.; Drinkwater, L.E. Agricultural Management and Labile Carbon Additions Affect Soil Microbial Community Structure and Interact with Carbon and Nitrogen Cycling. Microb. Ecol. 2013, 66, 158-170. [CrossRef]

12. Wang, X.; Cheng, H.; Zhang, J.; Huang, Q.; Deng, H.; Deng, Y.; Zhong, W. Long-term fertilization effects on active ammonia oxidizers in an acidic upland soil in China. Soil Biol. Biochem. 2015, 84, 28-37. [CrossRef]

13. Chen, C.; Zhang, J.; Min, L.; Qin, C.; Chen, Y.; Li, Y.; Huang, Q.; Wang, J.; Shen, Z.; Shen, Q. Microbial communities of an arable soil treated for 8 years with organic and inorganic fertilizers. Biol. Fertil. Soils 2016, 52, 1-13. [CrossRef]

14. Liu, L.; Li, T.; Wei, X.; Jiang, B.; Ping, F. Effects of a nutrient additive on the density of functional bacteria and the microbial community structure of bioorganic fertilizer. Bioresour. Technol. 2014, 172, 328-334. [CrossRef] [PubMed]

15. Yang, Y.; Wang, P.; Zeng, Z. Dynamics of Bacterial Communities in a 30-Year Fertilized Paddy Field under Different Organic-Inorganic Fertilization Strategies. Agronomy 2019, 9, 14. [CrossRef]

16. Lazcano, C.; Gomez-Brandon, M.; Dominguez, J.; Revilla, P. Short-term effects of organic and inorganic fertilizers on soil microbial community structure and function. Biol. Fertil. Soils 2013, 49, 723-733. [CrossRef]

17. Wei, M.; Hu, G.; Hui, W.; Bai, E.; Lou, Y.; Zhang, A.; Zhuge, Y. 35 years of manure and chemical fertilizer application alters soil microbial community composition in a Fluvo-aquic soil in Northern China. Eur. J. Soil Biol. 2017, 82, 27-34. [CrossRef]

18. Gu, S.; Hu, Q.; Cheng, Y.; Bai, L.; Liu, Z.; Xiao, W.; Gong, Z.; Wu, Y.; Feng, K.; Deng, Y. Application of organic fertilizer improves microbial community diversity and alters microbial network structure in tea (Camellia sinensis) plantation soils. Soil Tillage Res. 2019, 195, 104356. [CrossRef]

19. Ling, N.; Wang, D.; Chen, Z.; Yang, S.; Yu, G.; Wei, R.; Huang, Q.; Guo, S.; Shen, Q. Response of the population size and community structure of Paenibacillus spp. to different fertilization regimes in a long-term experiment of red soil. Plant Soil 2014, 383, 87-98. [CrossRef]

20. Murase, J.; Hida, A.; Ogawa, K.; Nonoyama, T.; Yoshikawa, N.; Imai, K. Impact of long-term fertilizer treatment on the microeukaryotic community structure of a rice field soil. Soil Biol. Biochem. 2015, 80, 237-243. [CrossRef]

21. Zhong, W.; Gu, T.; Wang, W.; Zhang, B.; Lin, X.; Huang, Q.; Shen, W. The effects of mineral fertilizer and organic manure on soil microbial community and diversity. Plant Soil 2010, 326, 511-522. [CrossRef]

22. Wang, J.; Xue, C.; Song, Y.; Wang, L.; Huang, Q.; Shen, Q. Wheat and Rice Growth Stages and Fertilization Regimes Alter Soil Bacterial Community Structure, But Not Diversity. Front. Microbiol. 2016, 7, 1207. [CrossRef] [PubMed]

23. Brookes, P.C.; Landman, A.; Pruden, G.; Jenkinson, D.S. Chloroform fumigation and the release of soil nitrogen: A rapid direct extraction method to measure microbial biomass nitrogen in soil. Soil Biol. Biochem. 1985, 17, 837-842. [CrossRef] 
24. Vance, E.D.; Brookes, P.C.; Jenkinson, D.S. An extraction method for measuring soil microbial biomass C. Soil Biol. Biochem. 1987, 19, 703-707. [CrossRef]

25. Tanja, M.; Salzberg, S.L. FLASH: Fast length adjustment of short reads to improve genome assemblies. Bioinformatics 2011, 27, 2957-2963.

26. Caporaso, J.G.; Kuczynski, J.; Stombaugh, J.; Bittinger, K.; Bushman, F.D.; Costello, E.K.; Fierer, N.; Peña, A.G.; Goodrich, J.K.; Gordon, J.I.; et al. QIIME allows analysis of high-throughput community sequencing data. Nat. Methods 2010, 7, 335-336. [CrossRef]

27. Edgar, R.C. UPARSE: Highly accurate OTU sequences from microbial amplicon reads. Nat. Methods 2013, 10, 996-998. [CrossRef]

28. Christian, Q.; Elmar, P.; Pelin, Y.; Jan, G.; Timmy, S.; Pablo, Y.; Jorg, P.; Frank Oliver, G.C. The SILVA ribosomal RNA gene database project: Improved data processing and web-based tools. Nucleic Acids Res. 2013, 41, 590-596.

29. Wang, Q.; Garrity, G.M.; Tiedje, J.M.; Cole, J.R. Naive Bayesian classifier for rapid assignment of rRNA sequences into the new bacterial taxonomy. Appl. Environ. Microbiol. 2007, 73, 5261-5267. [CrossRef]

30. Edgar, R.C. MUSCLE: Multiple sequence alignment with high accuracy and high throughput. Nucleic Acids Res. 2004, 32, 1792-1797. [CrossRef]

31. Geisseler, D.; Scow, K.M. Long-term effects of mineral fertilizers on soil microorganisms-A review. Soil Biol. Biochem. 2014, 75, 54-63. [CrossRef]

32. Marschner, P.; Kandeler, E.; Marschner, B. Structure and function of the soil microbial community in a long-term fertilizer experiment. Soil Biol. Biochem. 2003, 35, 453-461. [CrossRef]

33. Pan, Y.; Cassman, N.; De Hollander, M.; Mendes, L.W.; Korevaar, H.; Geerts, R.H.E.M.; Van Veen, J.A.; Kuramae, E.E. Impact of long-term N, P, K, and NPK fertilization on the composition and potential functions of the bacterial community in grassland soil. FEMS Microbiol. Ecol. 2014, 90, 195-205. [CrossRef] [PubMed]

34. Manna, M.C.; Swarup, A.; Wanjari, R.H.; Mishra, B.; Shahi, D.K. Long-term fertilization, manure and liming effects on soil organic matter and crop yields. Soil Tillage Res. 2007, 94, 397-409. [CrossRef]

35. Sapp, M.; Harrison, M.; Hany, U.; Charlton, A.; Thwaites, R. Comparing the effect of digestate and chemical fertiliser on soil bacteria. Appl. Soil Ecol. 2015, 86, 1-9. [CrossRef]

36. Wu, Y.; Zhao, C.; Farmer, J.; Sun, J. Effects of bio-organic fertilizer on pepper growth and Fusarium wilt biocontrol. Sci. Hortic. 2015, 193, 114-120. [CrossRef]

37. Diacono, M.; Montemurro, F. Long-term effects of organic amendments on soil fertility. A review. Agron. Sustain. Dev. 2010, 30, 401-422. [CrossRef]

38. Meidute, S.; Demoling, F.; Bååth, E. Antagonistic and synergistic effects of fungal and bacterial growth in soil after adding different carbon and nitrogen sources. Soil Biol. Biochem. 2008, 40, 2334-2343. [CrossRef]

39. Girvan, M.S.; Campbell, C.D.; Killham, K.; Prosser, J.I.; Glover, L.A. Bacterial diversity promotes community stability and functional resilience after perturbation. Environ. Microbiol. 2005, 7, 301-313. [CrossRef]

40. Janssen, P.H. Identifying the dominant soil bacterial taxa in libraries of 16S rRNA and 16S rRNA genes. Appl. Environ. Microbiol. 2006, 72, 1719-1728. [CrossRef]

41. Laurent, P.; Andersson, S.G.E.; Battin, T.J.; Prosser, J.I.; Schimel, J.P.; Whitman, W.B.; Sara, H. The ecological coherence of high bacterial taxonomic ranks. Nat. Rev. Microbiol. 2010, 8, 523-529.

42. Ai, C.; Liang, G.; Sun, J.; Wang, X.; Ping, H.; Wei, Z.; He, X. Reduced dependence of rhizosphere microbiome on plant-derived carbon in 32-year long-term inorganic and organic fertilized soils. Soil Biol. Biochem. 2015, 80, 70-78. [CrossRef]

43. Chen, X.; Zhang, L.M.; Shen, J.P.; Xu, Z.; He, J.Z. Soil type determines the abundance and community structure of ammonia-oxidizing bacteria and archaea in flooded paddy soils. J. Soils Sediments 2010, 10, 1510-1516. [CrossRef]

44. Chu, H.; Noah, F.; Lauber, C.L.; Caporaso, J.G.; Rob, K.; Paul, G. Soil bacterial diversity in the Arctic is not fundamentally different from that found in other biomes. Environ. Microbiol. 2010, 12, 2998-3006. [CrossRef]

45. Lauber, C.L.; Strickland, M.S.; Bradford, M.A.; Fierer, N. The influence of soil properties on the structure of bacterial and fungal communities across land-use types. Soil Biol. Biochem. 2008, 40, 2407-2415. [CrossRef]

46. Ling, N.; Chen, D.; Hui, G.; Wei, J.; Bai, Y.; Shen, Q.; Hu, S. Differential responses of soil bacterial communities to long-term N and P inputs in a semi-arid steppe. Geoderma 2017, 292, 25-33. [CrossRef]

47. Ramirez, K.S.; Craine, J.M.; Fierer, N. Consistent effects of nitrogen amendments on soil microbial communities and processes across biomes. Glob. Chang. Biol. 2012, 18, 1918-1927. [CrossRef] 
48. Eichorst, S.A.; Kuske, C.R. Identification of cellulose-responsive bacterial and fungal communities in geographically and edaphically different soils by using stable isotope probing. Appl. Environ. Microbiol. 2012, 78, 2316-2327. [CrossRef]

49. Lopes, A.R.; Bello, D.; Prieto-Fernández, Á.; Trasar-Cepeda, C.; Manaia, C.M.; Nunes, O.C. Relationships among bulk soil physicochemical, biochemical, and microbiological parameters in an organic alfalfa-rice rotation system. Environ. Sci. Pollut. Res. 2015, 22, 11690-11699. [CrossRef]

50. Ling, N.; Zhu, C.; Xue, C.; Chen, H.; Duan, Y.; Peng, C.; Guo, S.; Shen, Q. Insight into how organic amendments can shape the soil microbiome in long-term field experiments as revealed by network analysis. Soil Biol. Biochem. 2016, 99, 137-149. [CrossRef]

51. Wang, J.; Song, Y.; Ma, T.; Raza, W.; Li, J.; Howland, J.G.; Huang, Q.; Shen, Q. Impacts of inorganic and organic fertilization treatments on bacterial and fungal communities in a paddy soil. Appl. Soil Ecol. 2017, 112, 42-50. [CrossRef]

52. Beauregard, M.S.; Hamel, C.; Atul-Nayyar; St-Arnaud, M. Long-Term Phosphorus Fertilization Impacts Soil Fungal and Bacterial Diversity but not AM Fungal Community in Alfalfa. Microb. Ecol. 2010, 59, 379-389. [CrossRef] [PubMed]

53. Liu, J.; Peng, D.; Yang, G.; Zhu, H.; Zhu, H.; Fei, Z.; Zhong, Z. Effects of tree species and soil properties on the composition and diversity of the soil bacterial community following afforestation. For. Ecol. Manag. 2018, 427, 342-349. [CrossRef]

54. Zhalnina, K.; Dias, R.; Quadros, P.D.D.; Davis-Richardson, A.; Camargo, F.A.O.; Clark, I.M.; Mcgrath, S.P.; Hirsch, P.R.; Triplett, E.W. Soil pH Determines Microbial Diversity and Composition in the Park Grass Experiment. Microb. Ecol. 2015, 69, 395-406. [CrossRef] [PubMed]

(C) 2020 by the authors. Licensee MDPI, Basel, Switzerland. This article is an open access article distributed under the terms and conditions of the Creative Commons Attribution (CC BY) license (http://creativecommons.org/licenses/by/4.0/). 